\title{
PERFORMANCE CHANGES AROUND BANKS MERGERS AND ACQUISITIONS: EVIDENCE FROM POLAND
}

\author{
Katarzyna Budny \\ Cracow University of Economics, Cracow, Poland \\ e-mail: katarzyna.budny@uek.krakow.pl \\ ORCID: 0000-0002-3683-0327
}

\author{
Joanna Krasodomska \\ Cracow University of Economics, Cracow, Poland \\ e-mail: joanna.krasodomska@uek.krakow.pl \\ ORCID: 0000-0001-8423-678X
}

\section{Katarzyna Świetla}

Cracow University of Economics, Cracow, Poland

e-mail: katarzyna.swietla@uek.krakow.pl

ORCID: 000-0001-7796-9379

(C) 2019 Katarzyna Budny, Joanna Krasodomska, Katarzyna Świetla

This is an open access article distributed under the Creative Commons Attribution-NonCommercial-NoDerivs license (http://creativecommons.org/licenses/by-nc-nd/3.0/)

DOI: 10.15611/fins.2019.2.03

JEL Classification: G21, G34, M421

\begin{abstract}
This study investigates the influence of M\&A on the performance of banks operating in Poland. We use a sample of 14 transactions that occurred in the Polish banking sector from 2001 to 2015. Our data set includes pre and post-merger accounting information covering a period of two years before and after the merger. We follow Pilloff's [1996] approach to determine the average performance changes measured with ROAA and ROAE. According to the research results, M\&As transactions seem to affect profitability as both ROAA and ROAE means change. However, these changes do not follow the same trend. The correlations between the acquirer's pre-merger weighted performance measured with ROAA and ROAE and merger-related changes in performance are significant and negative. The same situation is observed as regards the target pre-merger weighted performance measured with ROAE and merger-related changes in performance. The results also suggest that large acquirers are associated with less successful M\&A.
\end{abstract}

Keywords: banks, M\&A, Poland, ROAA, ROAE. 


\section{Introduction}

The global financial environment is evolving rapidly. It is characterized by enhanced financial liberalisation and integration, the quick development of new financial products and technologies, increasing competition, and consolidation in the banking industry [Baltas et al. 2017]. In this paper we focus on the banks' mergers and acquisitions (M\&A). In the banking sector, the large wave of M\&A registered in the United States during the 1980s was followed a little later by a similar phenomenon in Europe, fostered by the II EU Directive on the Single Market [Caiazza et al. 2016]. The determinants and the effects of M\&A in the banking sector have been analyzed in the theoretical and empirical literature, with a particular focus on the US, the UK and West European countries [Tauseef, Nishat 2014]. M\&A, historically and currently, produce substantial efficiency gains associated with reduced operating costs, enhanced diversification, and the enrichment of bank-customer relationships [Calomiris 1999]. The available evidence shows that usually larger and more profitable banks acquire weaker institutions, with the aim to restructure and increase efficiency as a result of the synergy effect [Caiazza et al. 2016].

There are two main approaches used in the academic literature to investigate the efficiency and synergy effects of M\&A. The first set of studies uses the event study methodology, looking at the stock market reaction to the merger announcement. This methodology is based on the assumption of an efficient market where share prices react to new information in a timely and unbiased manner. Studies of this type do not address the issue of the actual gains resulting from consolidation and are based solely on market expectations [Kumar 2009; Shah and Kha 2017; Pilloff 1996]. The second group of studies uses the accounting performance indicators to compare the pre and post-merger performance. Such studies assume that the gains or losses resulting from a merger eventually appear in the firm's accounting records [Tuch, Sullivan 2007; Tauseef, Nishat 2014]. These studies examine the reported financial results (i.e. financial statements) of firms before and after M\&A to see how their financial performance has changed. The focus of these studies ranges across net income, return on equity or assets, leverage, and liquidity of the firm. Researchers usually use three (e.g. [Kumar 2009; Vennet 1996]) or two years of data before (e.g. [Pilloff 1996; Shakoor et al. 2014]), and two or three years after the merger event. The year of the merger is often omitted [Micek 2007]. The drawback of these studies is that the results are driven by accounting data that are based on historical figures and often neglect current market values [Pilloff 1996; Diaz et al. 2004]. Some of the studies are structured as matched sample comparisons, matching acquirers with nonacquirers based on industry and size of firm. In these studies, the question is whether the acquirers outperformed their non-acquirer peers [Bruner 2002].

In this paper, we adopt the approach based on pre and post-merger accounting data, and we apply it to the Polish conditions. Our motivation behind the choice of this particular context is that the banking sector in transition economies deserves 
special attention [Balcerowicz, Bratkowski 2001]. There is no economic growth in a country if its banking system does not function properly, and if it is not credible. Therefore the re-establishment of a sound banking sector has been crucially important for post-communist countries, such as Poland. Over the past few decades, the banking system in Poland has undergone significant structural reforms. As in other countries of Central and Eastern Europe (CEE), the main challenge was represented by the conversion of the communist banking systems into the market-oriented one in the 1990s. The transformation processes after 1997 (the so-called second period of the banking sector transition) involved banks' privatization and a the subsequent wave of M\&A, also with the participation of foreign private owners, especially international banking groups. Due to this fact, in Poland's contemporary banking system as elsewhere in the region, a significant percentage of banks' assets is owned by foreign investors [Claessens, van Horen 2001]. The latest government's idea of 'repolonising' the banking industry aims to restore Polish capital control over this sector [Miszerak, Rohac 2017].

The aim of the research we propose in this paper is to examine the effectiveness of M\&A in the Polish banking industry. From the 52 M\&A that have taken place in Poland since 1998, 14 transactions are included in our sample. We use the data provided by the Orbis and Notoria Database, Monitor Polski B, and the banks' websites. To measure the effects of M\&A we followed Pilloff's [1996] approach. According to the research results, M\&A transactions seem to affect profitability. The correlations between the acquirer's pre-merger weighted performance measured with ROAA, and ROAE and merger-related changes in performance are significant and negative. The same applies to the target pre-merger weighted performance measured with ROAE and merger-related changes in performance. The results also suggest that large acquirers are associated with less successful M\&A. Despite some limitations, the paper contributes to the understanding of the influence of M\&A on banks' performance.

The paper is organized as follows. Section two offers a literature review on the M\&A in the banking sector paying particular attention to research that uses accounting measures to compare the pre and post-merger performance. Section three discusses the banks' M\&A wave in Poland in a long-term perspective (1992-2017). Sections four and five present the research method and the results of the study, respectively. The last section offers a discussion and conclusions along with suggestions for further research.

\section{Literature review}

In the face of technological advancement, globalization and increased competition, there is a growing trend towards consolidation to reap the benefits through synergies, thereby enhancing efficiency and performance [Tauseef, Nishat 2014]. The term 'synergy' refers to the type of reaction that occurs when 'two substances or factors 
combine to produce a greater effect together than when the sum of the two operating independently could account for' [Gaughan (ed.) 1996]. Simply stated, synergy refers to the phenomenon that occurs when one plus one is more than two. The etymology of the word synergy indicates that it is derived from the Greek prefix 'syn' and the verb 'ergein' that make up the word 'synergeon' translated as 'working together' [Karenfort 2011]. According to Singh and Singh [2016], 'synergy is the soul of merger and acquisition'.

The term M\&A is English and includes all transactions that involve the sale or purchase of companies or parts of companies with a resultant change in the ownership structure, which is considered the main characteristic [Schade 2014, p. 4]. However, it should be noted that, despite the fact that these two terms: merger and acquisition are often used together, their meanings differ. Acquisition is a generic term used to describe a transfer of ownership. Merger is a narrow, technical term for a particular legal procedure that may or may not follow an acquisition [Reed et al. 2007]. A merger takes place when two or more businesses want to join forces and become a single entity. An acquisition occurs when a business is taken over by another party [Harvey 2015]. In a bank merger, two banks' balance sheets are combined into one, whereas a bank acquisition involves the two banks maintaining separate balance sheets within a single bank holding company [Kahn et al. 2000]. Throughout this paper the term M\&A is meant to describe both mergers and acquisitions.

We can distinguish three main types of M\&A: horizontal, vertical and conglomerate. A horizontal M\&A exists between companies that compete within the same industry segment. The main motives for the banks to get involved in these transactions are to increase the market share, improve the competitiveness or to realize cost synergies, such as economies of scale and scope [Schade 2014, p. 4]. A vertical M\&A occurs when two firms from the same industry, but different steps of the value chain, merge. This can take two basic forms: forward integration, whereby a firm buys a customer and backward integration, whereby a firm acquires a supplier. Conglomerate transactions involve the acquisition of companies from a wide range of industries that may or may not be interrelated. They can take many forms, ranging from short-term joint ventures to complete mergers. Conglomerate M\&A provide business with the possibility of getting access to new markets, find new business opportunities or lower their operational risk by diversification [Schade 2014, p. 5].

No matter which type of M\&A we consider, the main motive behind them is to create synergy. M\&A help the companies in getting the benefits of cost efficiency and greater market share [Khan 2011]. At the theoretical level, the underlying motivation for the integration of banks, as of other firms, is the achievement of efficiency improvements through cost reductions. Merging banks supposedly are capable of improving their operating costs by rationalizing the branch network, reducing back-office operations and common services and achieving higher economies of scale in information technology, brand recognition, and other fixed assets. Another rationale focuses on the market implications. M\&A allow banks to improve their market positions and increase their cross-selling of financial products [Campa, Hernando 2005]. 
Several empirical studies have been carried out to explore the synergy effect of banks' M\&A with the use of different measures. We review here only research studies that investigate the bank's pre and post-merger performance. Since the measures used by the authors to capture the change in performance are different, the results of the studies are often difficult to compare [Tauseef, Nishat 2014]. What is more, the authors' findings are not consistent. Some researchers observe an improvement in post-merger performance while other studies reveal that this is not the case.

Berger et al. [1999], provide a review of the causes and consequences of the consolidation of the financial services industry in the US. According to them, M\&A in the US banking industry improve the overall profit efficiency of the merged entity without any impact on its cost efficiency [Caiazza et al. 2016]. This result is partly supported by Cornett et al. [2006], who focus on 134 large US bank mergers between 1990 to 2000 and identify important improvements after the merger in the banks' operating performance (ROA, ROE, and Net Interest Margin). In another study, Berger et al. [2000] use data from five different countries - France, Germany, Spain, the UK and the US during the 1990s - to investigate the cross-border consolidation of financial institutions. They find that banks expanding to nearby regions tend to show better efficiency and profitability measures after the mergers.

M\&A in the European banking sector have been investigated by Vennet [1996], Altunbas and Ibáñez [2004], and Campa and Hernando [2005]. Vennet [1996], uses traditional measures of profitability as well as some efficiency measures to analyse the efficiency of a horizontal bank merger. The results indicate that domestic mergers among equal-sized partners significantly increase the performance of the merged banks; an improvement of cost efficiency is also found in cross-border acquisitions. In a more recent study, Altunbas and Ibáñez [2004], focus on the period of 1992-2001 and report a superior post-merger performance. According to their study, the estimated increase in return on equity (ROE) is of the order of $6 \%$ to $7 \%$, and it becomes significant two years after the completion of the deal. Campa and Hernando [2005] analyze the changes in the operating performance for the M\&A in European financial services industry during 1998-2002. They use measures of profitability (return on equity and net financial margin), solvency (capitalization ratio), efficiency (cost to income ratio), lending intensity (net loan to total assets) and risk profile (loan loss provisions to total assets and loan loss provisions to net financial margin). According to their findings, M\&A usually involved targets with an operating performance lower than the average in their sector. The transaction resulted in significant improvements in the target banks' performance, beginning on average two years after the transaction was completed. ROE of the target companies increased by an average of $7 \%$, and these firms also experienced efficiency improvements. There was also a significant positive impact on the net financial margin of the target banks. This effect decreases over time, and it is only significant in the first year after the deal.

Khan's [2011] study focuses on motivations for M\&A in the Indian banking sector. He investigates the performance of merged banks using such financial 
measures as gross-profit margin, net-profit margin, operating profit margin, return on capital employed (ROCE), return on equity (ROE), and debt-equity ratio. The combined performance of banks three years before the merger, and the performance of the acquiring bank three years after the merger, are compared. The results suggest that the efficiency and performance of the banks increased after the merger.

However, other studies reach different conclusions. Kwan and Wilcox [2002] analyze US bank mergers between 1985 and 1997 and find evidence of increased cost efficiency for the merged entity. A similar result was obtained by Carbo' et al. [2003] who assess the efficiency in 47 Spanish banks involved in M\&A and in 30 banks not involved in any M\&A during the period 1986-1998. No gain in efficiency for the merged entity has been found (see also [Caiazza et al. 2016]). Rezitis [2008] analysed the effect of M\&A on Greek banks. The results of the study indicate that the effects of mergers and acquisitions on technical efficiency and total factor productivity growth are rather negative.

In several cases the studies provide mixed results. Despite some positive effects of M\&A, negative tendencies are also observed. For example, Wadhwa and Syamala [2015] examine the operating performance of mergers not only at end level (ROA or ROE) but also analyze it at each stage of operation, i.e. material, labor, overheads, tax, interest and sales. In contrast to the above-presented studies, they do not find synergy creation at the end level (i.e. ROA level). In another study, Badreldin and Kalhoefer [2009] focus on Egyptian banks during the period 2002-2007. They investigate the post-merger operating performances of acquiring organizations on the basis of financial ratios analysis and find that some banks participating in M\&A processes have not shown significant improvements in performance and return on equity when compared to their performance before the deals. According to the research by Sufian and Habibullah [2013], which focuses on Malaysian banks', ROA and ROE were relatively higher during all post-merger years compared to the two years before the M\&A. However, the results seem to suggest that banks' credit risk was relatively higher during all the post-merger years compared to the three years before the M\&A. Similarly, Shakoor et al. [2014] used financial ratios related to profitability, liquidity, investment and solvency to analyze the impact of M\&A on banks' performance in Pakistan. Three ratios, profitability, solvency and investment, showed the negative impact of mergers and acquisitions on banks' performance.

In this study we follow Pilloff's [1996] methodology to a large extent. He investigates 48 mergers in the period 1982-1991 and compares consolidated premerger figures to post-merger profitability, efficiency, and balance sheet measures to measure the financial impact of M\&A on banks' performance. While the impact of mergers on performance is small on average, there is a great deal of cross-sectional variability in the changes following the mergers.

There are only a few empirical studies conducted by Polish authors which focus on the M\&A in the banking industry in Poland. Korzeb [2013] analyses pre and postmerger ROAA and ROAE ratios for 51 commercial banks during 1992-2009 and 
finds no significant improvement in the considered ratios. The aim of Havrylchyk's [2004] study is to analyze the M\&A that took place in Poland between 1997 and 2001. She uses an event study to measure the reaction of the capital market to the merger announcements, estimate changes in profitability and cost ratios, and investigate the development of productivity measured by the Malmquist index. The research results show that acquisitions are less successful than mergers in transferring prudent banking practices to the target banks.

\section{Banks' mergers and acquisitions in the Polish context}

Before 1989 the Polish banking system functioned as part of the centrally planned economy. The communist government determined interest rates by administrative decisions and the size and priorities of the banks' lending activities were recorded in the annual credit and cash plan. The National Bank of Poland (NBP) was the major element of the banking system and combined the functions of a commercial bank and a central bank [Kokoszczyński 2001; Kozak 2013].

The deregulation of 1989 contributed to the creation of a large group of small private banks and paved the way for privatization of the state-owned banks comprising the majority of the market. The M\&A in the 1990s had a limited impact on the banking sector as they resulted mostly from takeovers of the newly-created banks which became insolvent.

The course of the next stage of the banking sector's consolidation was associated with the enactment of the amended banking law in 1997. The introduced changes aimed at adjusting the banking regulations in Poland to European Union (EU) principles and increasing the confidence of foreign investors in the Polish banking sector. This period of the banking sector's development was characterized by M\&A which involved newly privatized banks [Balcerowicz, Bratkowski 2001].

The process of consolidation of the banking sector was significantly influenced by Poland's accession to the EU in May 2004. In subsequent years the financial crisis gave another impetus for M\&A, mostly due to the weakening financial condition and solvency of some EU and US banks, and the need to sell their Polish subsidiaries to pay back public aid funds. In 2004 there emerged branches of foreign credit institutions (Table 1).

Since 2010 the consolidation activities of banks have intensified, which restored the upward trend in the level of concentration of the Polish banking sector [Kozak 2013] (Figure 1).

The current situation in the Polish banking sector is characterized by a further decrease in the number of banks. In 2016 there were 36 commercial banks, 558 cooperative banks and 27 branches of credit institutions operating in Poland (Table 2). Around 170000 employees worked in some 15000 banking branches. The share of the ten biggest banks in the banking sector's total assets was $70.6 \%$ (table 2). $56.6 \%$ 
Table 1. The number of banks in Poland in 1989-2016

\begin{tabular}{|c|c|c|c|c|}
\hline Year & $\begin{array}{l}\text { Commercial } \\
\text { banks }\end{array}$ & $\begin{array}{l}\text { Cooperative } \\
\text { banks }\end{array}$ & $\begin{array}{c}\text { Foreign credit } \\
\text { institutions } \\
\text { branches }\end{array}$ & Total \\
\hline 1989 & 25 & 1663 & 0 & 1688 \\
\hline 1990 & 72 & 1666 & 0 & 1738 \\
\hline 1991 & 83 & 1663 & 0 & 1746 \\
\hline 1992 & 85 & 1663 & 0 & 1748 \\
\hline 1993 & 87 & 1653 & 0 & 1740 \\
\hline 1994 & 82 & 1612 & 0 & 1694 \\
\hline 1995 & 81 & 1510 & 0 & 1591 \\
\hline 1996 & 81 & 1394 & 0 & 1475 \\
\hline 1997 & 81 & 1295 & 0 & 1376 \\
\hline 1998 & 83 & 1189 & 0 & 1272 \\
\hline 1999 & 77 & 781 & 0 & 858 \\
\hline 2000 & 73 & 680 & 0 & 753 \\
\hline 2001 & 69 & 642 & 0 & 711 \\
\hline 2002 & 59 & 605 & 0 & 664 \\
\hline 2003 & 58 & 600 & 0 & 658 \\
\hline 2004 & 54 & 596 & 3 & 653 \\
\hline 2005 & 54 & 588 & 7 & 649 \\
\hline 2006 & 51 & 584 & 12 & 647 \\
\hline 2007 & 50 & 581 & 14 & 645 \\
\hline 2008 & 52 & 579 & 18 & 649 \\
\hline 2009 & 49 & 576 & 18 & 643 \\
\hline 2010 & 49 & 576 & 21 & 646 \\
\hline 2011 & 47 & 574 & 21 & 642 \\
\hline 2012 & 45 & 572 & 25 & 642 \\
\hline 2013 & 41 & 572 & 28 & 641 \\
\hline 2014 & 38 & 564 & 28 & 630 \\
\hline 2015 & 38 & 560 & 26 & 624 \\
\hline 2016 & 36 & 558 & 27 & 621 \\
\hline
\end{tabular}

Source: own elaboration based on the reports of Polish Financial Supervision Authority Reports and the Commission for Banking Supervision [Kozak 2013, p. 20]. 


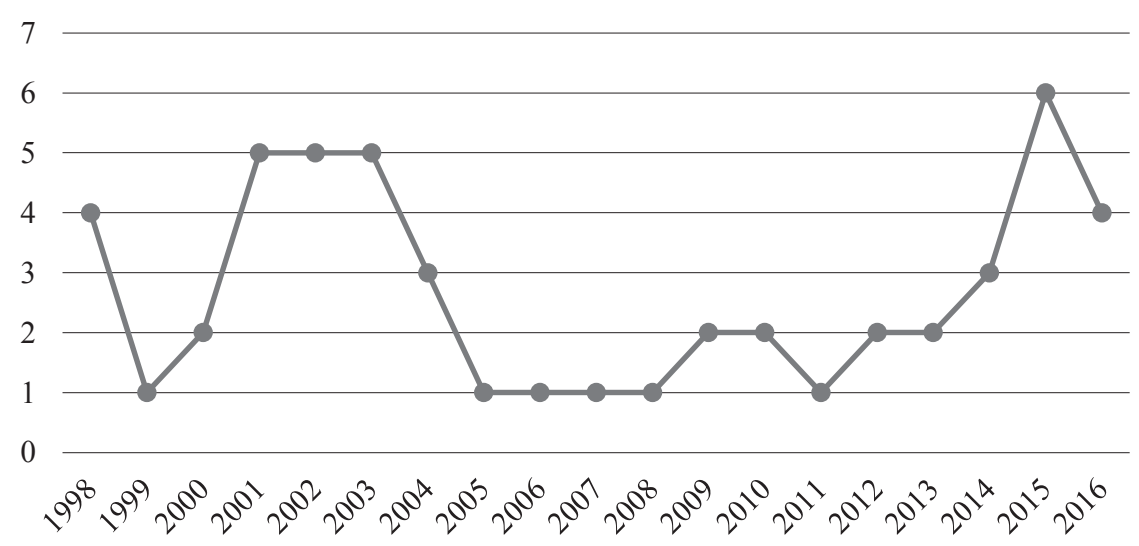

Fig. 1. M\&A in the Polish banking sector in 1998-2016

Source: Orbis Database (2017).

Table 2. Banking sector in Poland (2012-2016)

\begin{tabular}{|l|r|r|r|r|r|}
\hline \multicolumn{1}{|c|}{$\begin{array}{c}\text { Selected banking sector's } \\
\text { characteristics }\end{array}$} & 2012 & 2013 & 2014 & 2015 & 2016 \\
\hline Number of branches & 15412 & 15305 & 15062 & 14505 & 14476 \\
\hline Number of employees & 175071 & 174321 & 172659 & 170920 & 168839 \\
\hline The share of the industry assets: & & & & & \\
- banks controlled by domestic capital & $36.4 \%$ & $36.8 \%$ & $38.5 \%$ & $41 \%$ & $43.4 \%$ \\
- banks controlled by foreign capital & $63.6 \%$ & $63.2 \%$ & $61.5 \%$ & $59 \%$ & $56.6 \%$ \\
\hline The share of the industry assets: & & & & & \\
- five biggest banks & $45 \%$ & $46.1 \%$ & $48.5 \%$ & $48.8 \%$ & $48.3 \%$ \\
- ten biggest banks & $64.6 \%$ & $67.3 \%$ & $70.0 \%$ & $70.5 \%$ & $70.6 \%$ \\
\hline
\end{tabular}

Source: [Raport o sytuacji... 2017].

of banks' assets were controlled by foreign capital, mainly investors from Germany, Italy and Spain [Raport o sytuacji... 2017].

The decrease in the number of banks' branches and employees and the increase in the share in the banking sector's total assets of banks controlled by the domestic capital, as well as of the largest banks in the industry, is a consequence of M\&A and the so-called "repolonisation" strategy undertaken by the Polish government. In 2016 the three largest state-owned banks held assets worth 533 billion dollars and served 19.6 million customers, and Polish banking institutions were in possession of 194 billion dollars in assets and served 7 million customers. Thus, the amount of total assets controlled by both groups is about 720 billion dollars, which gives them a $43 \%$ market share [Samcik 2017]. The acquisition by the government of a controlling interest in a major Polish bank, Bank Pekao in June 2017, also fits in with this trend. 
The biggest Polish state-controlled insurance company, PZU, acquired $32.8 \%$ of the shares of Bank Pekao from the Italian bank UniCredit [Frączyk 2017].

\section{Empirical findings}

\subsection{Research aim and method}

The aim of the study presented in this paper is to examine the effectiveness of M\&A in the Polish banking industry. As far as the study's design is concerned, we follow Pilloff's [1996] approach. We investigate pre and post-merger performance with the use of ROAA and ROAE ratios. In the ROAA and ROAE calculation, net income figures are scaled by both average total assets and average total equity.

In order to measure the effectiveness of M\&A, the average performance $(X)$ of the two pre-merger years $(T-2, T-1)$ is compared with the average performance $(X)$ of the two post-merger years $(T+1, T+2)$ of the respective banks. Comparisons of the changes between the pre-merger and post-merger periods are made over a consistent set of individual banks described in the next subsection. Using Orbis Database, we identify a set of banks involved in M\&A since the establishment of the Polish banking sector until the present time. Data were gathered for the merger year $(T 0)$, and for years from -2 through +2 . Pre-merger variables require a distinction between acquirer and target institutions.

As in Pilloff's [1996] study, throughout this paper the performance measures (ROAA and ROAE) are referred to by variable $X$. The merger-related change in performance variable $X, \Delta X(j)$, is calculated as the difference between the pre-merger performance for the consolidated set of bank subsidiaries involved in merger $j, X_{\text {cons }}^{\text {pre }}$ $(j)$, and the post-merger performance for the same set of banks, $X_{\text {cons }}^{\text {post }}(j) . X_{\text {cons }}^{\text {pre }}$ is the average performance during the two years preceding the merger for the target and acquirer combined, and $X_{\text {cons }}^{\text {post }}$ is the average during the two years following the merger. $\Delta X$ is the difference between the pre-merger and post-merger performance. To compute $X_{\text {cons }}^{\text {pre }}(j)$, the pre-merger results are calculated from the average values of $X$ in years -2 and -1 . Likewise $X_{\text {cons }}^{\text {post }}(j)$, is calculated from years +1 and +2 .

According to Pilloff [1996] if the acquirer has a higher value of performance measure $\mathrm{X}$ than the target, then the acquisition may provide the opportunity for the acquirer to improve the performance of the target up to a point comparable with the premerger acquirer. The degree of this potential improvement is not only dependent on the performance difference between the two merging banks, but also on the relative size of the target and acquirer. If the target is small relative to the acquirer, then even if the target's operations are substantially improved, the net effect on the post-merger bank is minor. However, if the target is large, then only a small change in performance is needed to influence the post-merger bank. In particular, the weighted difference between acquirer and the target values of performance ratios may measure the potential for enhancement. According to Pilloff [1996], the weighted relative 
difference between acquirer and target pre-merger performance $\left(X^{R}(j)\right)$, can be determined as follows:

$$
X^{R}(j)=\frac{T(j)}{A(j)+T(j)}\left[X_{\text {acq }}^{\text {pre }}(j)-X_{\text {targ }}^{\text {pre }}(j)\right],
$$

where: $A(j)$ is the total assets held by the acquirer in merger $j$ at the start of the merger year, $T(j)$ is the total assets held by the target in merger $\mathrm{j}$ at the start of the merger year, $X_{a c q}^{p r e}(j)$ is the pre-merger adjusted values of variable $X$ for the acquirer, $X_{\text {targ }}^{\text {pre }}(j)$ is the pre-merger adjusted values of variable $X$ for the target.

$X_{a c q}^{p r e}(j)$ and $X_{\text {targ }}^{\text {pre }}(j)$ are computed in a similar manner as explained above, except that the acquirer and target are handled separately instead of together as a pro forma consolidated firm. $X^{R A}(j)$ is the weighted measure of acquirer pre-merger performance and $X^{R T}(j)$ is the weighted measure of target pre-merger performance.

Merger-related improvements may not be associated with the difference between acquirer and target performance, but may instead be influenced by the characteristics of just one of the banks involved in the acquisition. For example, high-performing acquirers may be banks which are most successfully able to integrate the acquired banks and generate gains. To examine the possibility that the acquirer is the key participant, $X^{R A}(j)$ is constructed with the restriction that $X_{\text {targ }}^{\text {pre }}(j)$ in the equation above is constrained to zero. Similarly, the pre-merger characteristics of the target may be important. Regardless of the acquirer, certain types of targets may be conducive to successful mergers. To examine this possibility, $X^{R T}(j)$ is constructed according to the equation (1) with $X_{\text {acq }}^{\text {pre }}(j)$ equal to zero.

Several other variables may influence merger outcomes. Both the absolute and relative size of the merger participants may play an important role in the ease with which consolidation can occur, changes in market power, or gains from scale economies. In the study, size is measured separately for acquirers (LNAAST) and targets (LNTAST) as the natural log of total assets at the start of the merger year. Relative size (RELSIZE) is the ratio of target assets to the sum of acquirer and target assets at the start of the merger year.

\subsection{Sample selection}

The sample consists of M\&A involving banking institutions that participated in only one major acquisition during a two-year time span. Every M\&A occurring between 1998 and 2017 that is listed in the Orbis Database and that satisfies certain requirements is included in the sample studied in this paper. Initially, 52 transactions were identified, 17 of which were excluded because there were other M\&A transactions involving either the acquirer or the target during the period from at least one year before the merger year to at least one year after it. Although the 
sample contains many of the largest and most notable M\&A of all those taking place from 1989 to 2017, it contains only a very small portion of all the deals that occurred during the period. This is mainly due to the difficulties with data availability. In the end, we focus only on 14 M\&A which took place between the years 2001-2015 (Table 3).

Data on the sample M\&A are collected from several sources. Information gathered from the Internet is used to construct detailed M\&A histories. Most of the bank balance sheet and income statement data are obtained from the Orbis Database and Notoria Database. The rest is derived manually from financial statements included in official journal of the government of the Republic of Poland - Monitor Polski B, and annual reports posted on the banks' websites.

Table 3 summarizes the mergers in the sample. Four transactions took place in 2001 and two in 2003. For each of the subsequent years only one transaction per year is included in the sample. The relative size mean of the full sample is $37.57 \%$. There are two transactions which represent extreme values of the relative size mean: 9.66\% (in 2008) and 98.25\% (in 2012).

Table 3. Summary of the mergers in the sample

\begin{tabular}{|c|c|c|c|c|c|c|c|c|}
\hline \multirow[b]{3}{*}{ Year } & \multirow[b]{3}{*}{$\begin{array}{c}\text { No of } \\
\text { Mergers }\end{array}$} & \multicolumn{7}{|c|}{ Total Assets (PLN thousands) at Start of Merger Years } \\
\hline & & \multicolumn{3}{|c|}{ Acquirer } & \multicolumn{3}{|c|}{ Target } & \multirow{2}{*}{$\begin{array}{c}\text { Relative } \\
\text { Size }\end{array}$} \\
\hline & & Mean & Minimum & Maximum & Mean & Minimum & Maximum & \\
\hline 2001 & 4 & 22184490 & 11161489 & 41074796 & 13934488 & 3344191 & 25124175 & 36.02 \\
\hline 2003 & 2 & 12961215 & 1072863 & 24849566 & 1330440 & 111502 & 2549377 & 35.41 \\
\hline 2007 & 1 & 2156506 & 2156506 & 2156506 & 2665963 & 2665963 & 2665963 & 55.28 \\
\hline 2008 & 1 & 119568556 & 119568556 & 119568556 & 12784112 & 12784112 & 12784112 & 9.66 \\
\hline 2009 & 1 & 19886304 & 19886304 & 19886304 & 2871886 & 2871886 & 2871886 & 12.62 \\
\hline 2010 & 1 & 33044879 & 33044879 & 33044879 & 24016417 & 24016417 & 24016417 & 42.09 \\
\hline 2011 & 1 & 9968460 & 9968460 & 9968460 & 6198498 & 6198498 & 6198498 & 38.34 \\
\hline 2012 & 1 & 957111 & 957111 & 957111 & 53307188 & 53307188 & 53307188 & 98.24 \\
\hline 2013 & 1 & 59196103 & 59196103 & 59196103 & 40258606 & 40258606 & 40258606 & 40.48 \\
\hline 2015 & 1 & 196279932 & 196279932 & 196279932 & 32855745 & 32855745 & 32855745 & 14.34 \\
\hline $\begin{array}{l}\text { Full } \\
\text { Sample }\end{array}$ & 14 & 39694160 & 957111 & 119568556 & 16668375 & 111502 & 53307188 & 37.57 \\
\hline
\end{tabular}

* Note: Relative size equals target total assets divided by acquirer plus target total assets measured at the start of the merger year.

Source: own study. 


\subsection{Results}

\section{Mean Performance Changes}

Table 4 presents the mean levels of pre-merger and post-merger adjusted performance measured with ROAA and ROEA, and the average change (mean $\Delta X$ ) between the two periods.

Table 4. Performance: pre-merger, post-merger and changes

\begin{tabular}{|c|c|c|c|c|c|c|}
\hline $\begin{array}{c}\text { Performance } \\
\text { Measure } X\end{array}$ & $\begin{array}{c}\text { Mean } \\
X_{\text {cons }}^{\text {pre }}\end{array}$ & $\begin{array}{c}\text { Mean } \\
X_{\text {cons }}^{\text {post }}\end{array}$ & Mean $\Delta X$ & $\begin{array}{c}\text { Tenth } \\
\text { Percentile } \\
\text { of } \Delta X\end{array}$ & $\begin{array}{c}\text { Ninetieth } \\
\text { Percentile } \\
\text { of } \Delta X\end{array}$ & $\begin{array}{c}\text { Standard } \\
\text { Deviation } \\
\text { of } \Delta X\end{array}$ \\
\hline ROAA & $-1.13 \%$ & $0.81 \%$ & $1.94 \%$ & $-1.47 \%$ & $14.22 \%$ & $6.33 \%$ \\
\hline ROAE & $-1.62 \%$ & $-3.87 \%$ & $-2.25 \%$ & $-75.69 \%$ & $67.86 \%$ & $47.95 \%$ \\
\hline
\end{tabular}

Source: own study.

Profitability seems to be affected by M\&A transactions as both pre and postmerger ROAA and ROAE are different. However, these changes do not follow the same trend. According to the results presented in Table 4, the mean difference between banks' pre-merger and post-merger performance measured with ROAA is positive at the level of $1.94 \%$. At the same time, the mean difference between premerger and post-merger performance measured with ROAE is negative at the level of $-2.25 \%$.

\section{Cross-sectional Analysis of Performance Changes}

Table 5 reports the results that illustrate the relationship between target $\left(X^{R T}\right)$ and acquirer $\left(X^{R A}\right)$ pre-merger weighted performance and the merger-related change in performance $(\Delta X)$ measured with ROAA and ROAE. The $X^{R}$ variable is the weighted difference between the acquirer and target pre-merger performance.

Table 5. Correlation of performance changes with pre-merger performance variables

\begin{tabular}{|l|l|l|l|}
\hline Performance Measure $X$ & $\operatorname{Corr}\left(\Delta X, X^{R}\right)$ & $\operatorname{Corr}\left(\Delta X, X^{R A}\right)$ & $\operatorname{Corr}\left(\Delta X, X^{R T}\right)$ \\
\hline ROAA & $-0.94965^{* *}$ & $-0.95325^{* *}$ & -0.40933 \\
\hline ROAE & $-0.59648^{*}$ & $-0.59331^{*}$ & $-0.56962^{*}$ \\
\hline
\end{tabular}

Note: $\left.{ }^{* *}\right)$ indicates significance at the 5 percent $(1$ percent) level.

Source: own study.

According to the information provided in Table 5, the $X^{R}$ variables have a negative influence on merger-related performance changes as $\operatorname{Corr}\left(\Delta X, X^{R}\right)$ is significant for both ROAA and ROAE. The correlations between the acquirer pre-merger weighted performance measured with ROAA and ROAE and the merger-related 
change in performance are significant and negative. The same applies to the target pre-merger weighted performance measured with ROAE and the merger-related change in performance. This indicates that the efficiency of M\&A is high when (1) the acquirer profitability measured with ROAA and ROAE is low and when (2) the target profitability measured with ROAE is low.

Table 6. Correlation of performance changes with size variables

\begin{tabular}{|l|c|c|c|}
\hline Performance Change $\Delta \mathrm{X}$ & $\operatorname{Corr}(\triangle \mathrm{X}$, LNAAST $)$ & $\operatorname{Corr}(\triangle \mathrm{X}$, LNTAST $)$ & $\operatorname{Corr}(\triangle \mathrm{X}$, RELSIZE $)$ \\
\hline$\triangle \mathrm{ROAA}$ & $-0.531^{*}$ & 0.116 & $0.553^{* *}$ \\
\hline$\triangle \mathrm{ROAA}$ & -0.321 & 0.095 & 0.452 \\
\hline
\end{tabular}

Note: $* * *)$ indicates significance at the 10 percent $(5$ percent $)$ level.

Source: own study.

The results regarding the correlations involving size variables are reported in Table 6. They suggest that large acquirers are associated with less successful M\&A. The absolute size of the acquirer is related to post-merger improvement, as LNAAST is significantly negatively related to the ROAA profitability measure, which means that the bigger the acquirer the lower the M\&A efficiency. The absolute size of the target, LNTAST, is not significantly related to changes in banks' performance. RELSIZE, which is the ratio of target assets to the sum of acquirer and target assets at the start of the merger year, is positively associated with the change in profitability measured with ROAA.

\section{Conclusions and future research}

In this paper we analyze the theory of M\&A efficiency which holds that M\&A are executed in order to achieve synergy benefits. The banks' consolidation is a continuous process which depends on the degree of the financial system's development and the macroeconomic situation of the country. The major drivers of M\&A can be related to the environment in which the banks operate (i.e. economy transformation or regulatory changes) or the banks themselves (i.e. restructuring procedures, utilization of the economies of scale and scope, and improvement of market position).

In Poland, the wave of M\&A wave was preceded by the de-monopolization of the banking sector which started in 1989 and the privatization of the state-owned banks. It is expected that the consolidation processes will continue to be a presentday characteristic of the modern banking landscape in Poland. However, in contrast to the previous years, when they were driven mostly by foreign investors, their aim will be to increase the Polish capital share in the banking sector, which is in line with current governmental policy.

In this paper we attempt to measure the consequences of $14 \mathrm{M} \& \mathrm{~A}$ that took place in the Polish banking sector between 2001 and 2015. To assess the efficiency 
of M\&A we analyze the pre and post-merger performance of banks, measured with ROAA and ROAE.

Similarly to Badreldin and Kalhoefer [2009], Shakoor et al. [2014] and Korzeb [2013], we do not find a significant positive effect of M\&A on the performance of banks participating in the deal. By examining the changes in the level of ROAA and ROAE, we found that the mean difference between the pre-merger and post-merger performance measured with ROAA is positive and the mean difference between the pre-merger and post-merger performance measured with ROAE is negative.

We believe that our research contributes to the existing literature on M\&A by examining the efficiency of M\&A in Poland. We think that it extends the previous study by Korzeb [2013] because we eliminate the M\&A transactions involving the acquirer or target during the period from at least one year before the year of the merger in question to at least one year after it. However, this results in a relatively small sample.

Admittedly, the study reported in this paper is not free from limitations. The most important one is the small sample. This is due to the fact that a comprehensive database was not available and the data was mostly collected by hand; in several cases it was impossible to obtain historical data. Extending the sample to other Central and Eastern European (CEE) countries might be useful in order to get access to a larger amount of data. The second limitation is restricting the number of financial measures only to ROAA and ROAE.

The present paper could be extended on several fronts. First, additional financial measures, apart from ROAA and ROAE, could be included in the analysis, which might relate to banks' profitability (e.g. net profit margin), efficiency (e.g. total costs scaled by average assets, total costs scaled by average revenues) and balance sheet (e.g. personnel costs scaled by average assets, total noninterest expenses scaled by average assets, capital to assets, loans to assets, core deposits to assets). Second, further studies might focus on the investigation of the impact of M\&A on nonfinancial banks' performance measures such as employment, number of branches or number of clients. Third, regarding research methodology, some other methodological approaches and analyses could be undertaken to study this topic. The analysis could also include similar banks which were not involved in M\&A in the years under investigation (peers) and compare their results with the post-merger results of banks that participated in M\&A. Another approach, such as event study methodology, can also be applied to confirm the results. The importance of the human factor in successful M\&A also seems to be worth investigating.

\section{References}

Altunbas Y., Ibáñez M.D., 2004, Mergers and acquisitions and bank performance in Europe. The role of strategic similarities, ECB Working Paper, vol. 398, pp. 1-35. 
Badreldin A., Kalhoefer C., 2009, The Effect of Mergers and Acquisitions on Bank Performance in Egypt, Working Paper, vol. 18, pp. 1-15.

Balcerowicz E., Bratkowski A., 2001, Restructuring and Development of the Banking Sector in Poland. Lessons to be Learnt by Less Advanced Transition Countries, Case Reports, Centrum Analiz Społeczno-Ekonomicznych, vol. 44, pp. 1-38.

Baltas K.N., Kapetanios G., Izzeldin M., 2017, Liquidity creation through efficient M\&A: A viable solution for vulnerable banking systems? Evidence from a stress test under a panel VAR methodology, Journal of Banking \& Finance, vol. 83, pp. 36-56.

Berger A.N., Demsetz R.S., Strahan P.E., 1999, The consolidation of the financial services industry: causes, consequences and implications for the future, Journal of Banking \& Finance, vol. 23, pp. 135-194.

Berger A.R., DeYoung R., Genay H., Udell G.F., 2000, Globalization of Financial Institutions: Evidence from Cross-Border Banking Performance, The Brookings-Wharton Papers on Financial Services, vol. 3, pp. 23-158.

Bruner R.F., 2002, Does M\&A pay?, Journal of Applied Finance, vol. 12, no. 1, pp. 48-68.

Caiazza S., Pozzolo A.F., Trovato G., 2016, Bank efficiency measures, M\&A decision and heterogeneity, Journal of Productivity Analysis, vol. 46, no. 1, pp. 25-41.

Calomiris C.W, 1999, Gauging the efficiency of bank consolidation during a merger wave, Journal of Banking \& Finance, vol. 23, pp. 615-621.

Campa J.M., Hernando I., 2005, M\&A performance in the European financial industry, Documentos de Trabajo no. 0516, Banco Espana, pp. 1-27.

Carbo V.S., Humphrey D.B., Fernandez F.R., 2003, Bank deregulation is better than mergers, Journal of International Financial Markets, Institutions and Money, vol. 13, no. 5, pp. 429-449.

Cornett M.M., McNutt J.J., Tehranian H., 2006, Performance changes around bank mergers: revenue enhancements versus cost reductions, Journal of Money, Credit and Banking, vol. 38, no. 4, pp. 1013-1050.

Diaz B.D., Olalla M.G, Azofra S.S., 2004, Bank acquisitions and performance: evidence from a panel of European credit entities, Journal of Economics and Business, vol. 56, pp. 377-404.

Frączyk J., 2017, Repolonizacja banków zakończona, https://www.money.pl/gospodarka/wiadomosci/ artykul/repolonizacja-bankow-pekao-pzu-pfr,81,0,2329681.html (28.11.2017).

Gaughan P.A. (ed.), 1996, Mergers, Acquisitions and Corporate Restructurings, John Wiley \& Sons, New York.

Harvey S.K., 2015, The role of mergers and acquisitions in firm performance: A Ghanaian case study, Journal of Applied Business and Economics, vol. 17, no. 1, pp. 66-77.

Havrylchyk O., 2004, Consolidation of the Polish banking sector: consequences for the banking institutions and the public, Economic Systems, vol. 28, pp. 125-140.

Irfan S.M., Nawaz M., Zulqarnain A.M., Khan W.A., 2014, Do mergers and acquisitions vacillate the banks performance, Research Journal of Finance and Accounting, vol. 5, no. 6, pp. 123-137.

Kahn C., Pennacchi G., Sopranzetti B., 2000, Financial Institutions Center Bank Consolidation and Consumer Loan Interest Rates, The Wharton School, University of Pennsylvania, pp. 1-36.

Karenfort S., 2011, Synergy in Mergers \& Acquisition: The Role of Business Relatedness, Josef EUL Verlag, Koln, pp. 1-121.

Khan A.A., 2011, Merger and acquisitions (M\&As) in the Indian banking sector in post liberalization regime, International Journal of Contemporary Business Studies, vol. 2, no. 11, pp. 31-45

Kokoszczyński R., 2001, Structural changes in the Polish banking industry in three dimensions of consolidation processes in an emerging economy. The banking industry in the emerging market economies: competition, consolidation and systemic stability, Bank for International Settlements, vol. 4, pp. 118-122.

Komisja Nadzoru Finansowego, 2017, Publikacje i opracowania, https://www.knf.gov.pl/publikacje_ i_opracowania (15.11.2017). 
Korzeb Z., 2013, Ocena fuzji i przejęć w polskim sektorze bankowym z wykorzystaniem wskaźników rentowności (ROAA,ROAE), Zarządzanie i Finanse, no. 2, pp. 321-331.

Kozak S., 2013, Consolidation of the banking sector in Poland in 1989-2013 in comparison with the structural changes of the banking sector in the USA and the EU, Economic Institute, NBP Working Paper, vol. 166, pp. 1-55.

Kumar R., 2009, Post-merger corporate performance: an Indian perspective, Management Research News, vol. 32, no. 2, pp. 145-157.

Kwan S., Wilcox J., 2002, Hidden cost reduction in bank mergers: accounting for more productive banks, [in:] A.H. Chen (ed.), Research in Finance, Elsevier Press, San Diego, 19, pp. 109-124.

Micek M., 2007, Przegląd metod oceny efektów konsolidacji banków, Bank i Kredyt, no. 4, pp. 54-66.

Miszerak M., Rohac R., 2017, Poland's rush to banking sector socialism, Financial Times, https:// www.ft.com/content/f7283548-5cd1-11e7-b553-e2df1b0c3220 (20.11.2017).

Pilloff S.J., 1996, Performance changes and shareholder wealth creation associated with mergers of publicly traded banking institutions, Journal of Money, Credit and Banking, vol. 28, no. 3, pp. 294-310.

Raport o sytuacji banków w 2016, 2017, Urząd Komisji Nadzoru Finansowego Warszawa, https://bip. knf.gov.pl/pliki/RAPORT_O_SYTUACJIBANKOW_2016_59975_tcm6-5997.

Reed S.F., Reed L.A., Nesvold H.P. (eds.), 2007, The Art of $\bar{M} \& A . \bar{A}$ Merger/Acquisition/Buyout Guide, Mc Graw Hill, New York.

Rezitis A.N., 2008, Efficiency and productivity effects of bank mergers: Evidence from the Greek banking industry, Economic Modelling, vol. 25, pp. 236-254.

Samcik M., 2017, Banki w polskich rękach. Czy repolonizacja Pekao wptynie na ograniczenie konkurencji i podwyzki cen ustug bankowych?, http://wyborcza.pl/7,155287,21784404,banki-w-polskich-rekach-czy-repolonizacja-pekao-wplynie-na.html (28.11.2017).

Schade V., 2014, Successful management of mergers \& acquisitions: development of a synergy tracking tool for the post merger integration, Anchor Academic Publishing, pp. 1-72.

Shakoor M.J., Nawaz M., Asab M.Z., Khan W.A., 2014, Do mergers and acquisitions vacillate the banks performance? An evidence from Pakistan banking sector, Research Journal of Finance and Accounting, vol. 5, no. 6, p. 123-137.

Shah B.A., Khan N., 2017, Impacts of mergers and acquisitions on acquirer banks' performance, Australasian accounting, Business and Finance Journal, vol. 11, pp. 30-54.

Singh P, Singh K., 2016, Exploring synergies in bank mergers, A case study, Finance India, vol. XXX, no. 1, pp. 141-152.

Sufian F., Habibullah M.S., 2013, The impact of forced mergers and acquisitions on banks'total factor productivity: empirical evidence from Malaysia, Journal of the Asia Pacific Economy, vol. 19, no. 1, pp. 151-185.

Tauseef S., Nishat M., 2013, Wealth effect of mergers \& acquisitions in emerging markets: the case of Pakistan's banking sector, Business Review, vol. 9, no. 2, pp. 1-14.

Urząd Komisji Nadzoru Finansowego, 2017, Raport o sytuacji banków w 2016, Warszawa, pp. 1-120.

Van Horen N., Claessens S., 2001, Being a foreigner among domestic banks: asset or liability, IMF Working Papers, pp. 1-35.

Vennet R.V., 1996, The effect of mergers and acquisitions on the efficiency and profitability of EC credit institutions, Journal of Banking \& Finance, vol. 20, no. 9, pp. 1531-1558.

Wadhwa K., Syamala R.S., 2015, An empirical examination of efficiency theory of mergers in the emerging market of India, Theoretical Letters, vol. 5, pp. 757-774. 


\section{ZMIANY W WYNIKACH DZIAŁALNOŚCI BANKÓW JAKO EFEKT FUZJI I PRZEJĘĆ: PRZYKLAD POLSKI}

Streszczenie: W artykule zbadano wpływ fuzji i przejęć na wyniki banków działających w Polsce. Analizą objęto 14 transakcji M\&A w sektorze bankowym od 2001 do 2015 r. Badania dotyczą okresu dwóch lat przed i dwóch po transakcji. Zastosowano podejście oparte na badaniach Pilloffa [1996] i ustalono średnie zmiany rentowności banków z wykorzystaniem ROAA i ROAE. Wyniki wskazują, że fuzje i przejęcia wpływają na rentowność badanych banków, gdyż średnie wartości ROAA i ROAE ulegają zmianie. Korelacja pomiędzy rentownością banku nabywcy mierzoną za pomocą ROAA i ROAE i jej zmianą będącą wynikiem transakcji jest istotna i negatywna. Sytuacja taka ma miejsce $\mathrm{w}$ odniesieniu do rentowności nabywanego banku przed transakcją mierzonej z wykorzystaniem ROAE i zmianą rentowności będącą wynikiem transakcji. Wyniki badań wskazują, że mniej efektywne transakcje są domeną dużych nabywców. Wyniki badań stanowią wkład w dotychczasowy dorobek literatury w badanym zakresie.

Słowa kluczowe: banki, fuzje i przejęcia, Polska, ROAA, ROAE. 